\title{
MODEL OF PREVENTION OF TRAFFIC ACCIDENTS
}

\author{
Ismail, Haryono, Permana Tedjo \\ e-mail : ismail@ubhara.ac.id
}

\begin{abstract}
Traffic accidents are a leading indicator of the level of road safety. In developed countries safety problems are a very considered problem in order to reduce the problem of accidents that occur. The high number of traffic accidents is caused by several factors, but the most dominant are human factors. Many accidents occur on the road due to traffic accidents, this is because many people do not yet know the meaning or purpose of the signs on the road, and the community does not understand the meaning of signs for the community regarding participation in approving traffic signs. The research objectives are 1) Overcoming Traffic Accidents Experiencing Cross-Road Traffic Accidents 2) Making Traffic Accident Models Through Education For Drivers / Pedestrians.

The research in this discussion uses a qualitative descriptive method. There are 5 causes of traffic accidents, namely: Human Error Factors, Traffic Sign Factors, Road Factors, Motor Vehicle Factors, Natural Factors. Efforts to prevent traffic accidents can be done with education through videotron, pocketbooks and media online for road users traffic and related parties about driving safety behavior and traffic ethics, the unique trendy accessories and shirts with technology reflectors to the safety of road traffic, the preparation of a database of traffic accident, spot make eco smart trafficlight as a violation of traffic lights, detection make the notification system the traffic signal an android in every motor vehicles to reduce traffic offenses, building the technology for detecting the shock drowsiness on the motorist with a system computer vision as a step minimalisir traffic accidents, make the system intelligent transportation for traffic, community empowerment bikers as role models a pioneer of orderly traffic
\end{abstract}

Keywords: Traffic, Accidents. 
Proceeding ICOGISS 2019

Page 838-849.. ISBN: 978-602-6 988-75-1

Web Jurnal Online: jurnal.unmuhjember.ac.id

By: Ismail, Haryono, Permana Tedjo

Model Of Prevention Of Traffic Accidents

\section{INTRODUCTION}

Traffic signs are part of road equipment containing symbols, letters, numbers, sentences or a combination of them, which serves as a warning or notification for road users. Traffic accidents are the main indicator of the level of road safety. In developed countries the problem of road safety is a matter of great concern in order to reduce the quantity of accidents that occur. This is an indicator of the importance of understanding accident characteristics (Maya, 2011). East Java Regional Police held a release of performance analysis and evaluation throughout 2018, claimed to have decreased the number of traffic accidents. The decrease in the number of traffic accidents was around $1.87 \%$ ie 22,655 cases in 2018 and 22,231 cases in 2019 (Jawa Pos.com, 2019)

According to the World Health Organization (WHO) published in the Global Report on Road Safety, explained that as many as 1.25 million people were victims of traffic accidents and every year as many as 20-50 million people were injured in traffic accidents. WHO also mentions that child deaths in the world can be caused due to traffic accidents. On average every day there are 1000 deaths in the age range 10-24 years, in addition to that $54 \%$ of the contributors to deaths from traffic accidents in the world come from middle and low income countries. Based on data from the Indonesian National Police, the number of traffic accidents based on the type of vehicle, motorcycle is the vehicle that ranks the highest contributor to traffic accidents, amounting to 108,883 cases, while the second rank is occupied by passenger cars by 18,147 cases, car loads by 19,242 cases , 4,808 bus cases, and 1,050 special vehicles. This can be caused by the lack of awareness of motorcyclists about safe driving which can reduce the risk of traffic accidents. (Defia, 2018)

The high number of traffic accidents is caused by several factors, but the most dominant is the human factor. Violation of traffic signs is one of the causes of traffic accidents. The violation is caused due to deliberate or lack of self-control on the driver of applicable regulations. Motorcyclists who commit violations occur because of low self-control from the driver. Similarly, personality factors can also influence violations so that it can cause traffic accidents (Kusumadewi, 2012). Kasat Lantas Polrestabes Surabaya AKBP Eva Guna Pandia mentioned the number of traffic accidents involving millennial in Surabaya, reaching 45\%, Pandia hopes that the event of the Millennial Road Festival can increase public awareness about traffic safety (TribunJatim.com, 2019). According to the research of Nabi et al (2005), humans are the biggest factor contributing to the highest number of traffic accidents. The behavior of the intended motor vehicle driver is a violation of the law, as well as how to drive.

Traffic is one of the means of public communication that plays a vital role in facilitating nation development. One of the things encountered in traffic is an accident. This problem generally occurs when transportation facilities, both in terms of roads, vehicles and other supporting facilities have not been able to keep up with developments in the community. 
Many accidents that occur on the road due to traffic violations, this is because many people do not know the meaning or purpose of the signs on the road, and the public does not understand the meaning of the traffic signs that are on the road, also due to lack of socialization towards community regarding the importance of obeying traffic signs.

At present the socialization is done just to give direction to the community by way of going directly to the community and conducting socialization to schools, but the way it is done looks simple, the traffic police only explains the material of socialization by using a power point presentation wherein the power point is only contains images and brief descriptions of the images displayed. In addition, the traffic police usually use props where the props require a large enough space to store them, so that the public will feel bored because there is no animation effect that is used as well as limited props. The importance of traffic safety education is needed so that road users, especially motor vehicle drivers are able to make decisions, identify or assess risks and strategies to minimize risks. The right way is needed to educate motorized vehicle drivers who are expected to increase awareness of the importance of a safe, orderly, and safe attitude while driving on the highway.

Literature review

Traffic accident

The definition of accident according to the Road Traffic and Transport Law Number 22 Year 2009 states "A traffic accident is an unexpected and unintentional road event involving a vehicle with or without other road users that results in human casualties and / or property loss. "Accidents can be classified based on several factors. Traffic accident characteristics are characteristics or characters that can be used as a description (descriptive) of traffic accidents that occur in the form of grouping / classification. Traffic accidents that occur on different roads, both toll roads and non-toll roads. Non-toll roads also have different characteristics between inner-city, inter-city roads and inter-provincial roads. Accidents can be caused by road user factors (drivers and pedestrians), vehicle factors and environmental factors. Accidents are caused by a combination of several factors of bad behavior from drivers or pedestrians, roads, vehicles, drivers or pedestrians, bad weather or bad views. Some experts classify factors that cause accidents into three groups, namely road user factors (human), vehicle factors and road and environmental factors.

According to Utari (2010), the biggest cause of traffic accidents in Indonesia is the human factor of $89.5 \%$, where the role of humans as the driver is $82.39 \%$ and as pedestrians $7.11 \%$, vehicle factor $4.8 \%$, road factor highway $5.05 \%$, and environmental factors $0.65 \%$. Chen (2009) states that risk attitude has a significant effect on risky driving behavior, this indicates the more someone has a risk taker personality, the greater the chance of being involved in an accident. Gregersen et al. (2003) stated that the high number of accidents that occurred in Sweden involved novice drivers caused by lack of knowledge, insight, driving experience, lack of emotional maturity and risk-like challenges.

Research methods 
Page 838-849.. ISBN: 978-602-6 988-75-1

Web Jurnal Online: jurnal.unmuhjember.ac.id

By: Ismail, Haryono, Permana Tedjo

Model Of Prevention Of Traffic Accidents

According to Utari (2010), the biggest cause of traffic accidents in Indonesia is the human factor of $89.5 \%$, where the role of humans as the driver is $82.39 \%$ and as pedestrians $7.11 \%$, vehicle factor $4.8 \%$, road factor highway $5.05 \%$, and environmental factors $0.65 \%$. Chen (2009) states that risk attitude has a significant effect on risky driving behavior, this indicates the more someone has a risk taker personality, the greater the chance of being involved in an accident. Gregersen et al. (2003) stated that the high number of accidents that occurred in Sweden involved novice drivers caused by lack of knowledge, insight, driving experience, lack of emotional maturity and risk-like challenges.

Research methods

Research Results and Discussion

Identify Causes of Increased Traffic Accidents

Accidents do not happen by accident, but there is a reason. The cause of the accident must be analyzed and discovered, so that corrective action against the cause can be carried out and with further preventive efforts the accident can be prevented. There are several factors that can cause accidents on the highway to occur, namely: human error or human error, mechanical failure or vehicle technical errors, road condition factors, and weather factors. The causes of traffic accidents are classified into three elements, namely: human (Human Error), Traffic Signs, and Street. While based on data from the Regional Traffic Management Center of the Traffic Directorate of the East Java Regional Police (RTMC Ditlantas Polda East Java) the factors causing traffic accidents are as follows:

Table 1 Factors Causing Traffic Accidents

\begin{tabular}{|r|l|r|r|r|r|}
\hline \multirow{2}{*}{ No } & \multirow{2}{*}{ Uraian } & \multicolumn{2}{c|}{ Tahun } & \multicolumn{2}{c|}{ Trend } \\
\cline { 3 - 6 } & & $\mathbf{2 0 1 7}$ & \multicolumn{1}{c|}{$\mathbf{2 0 1 8}$} & \multicolumn{1}{c|}{ Angka } & \multicolumn{1}{c|}{$\%$} \\
\hline 1 & Manusia & 9.686 & 10.745 & 1.059 & 10,93 \\
\hline 2 & Jalan & 567 & 817 & 250 & 44,09 \\
\hline 3 & Kendaraan & 88 & 113 & 25 & 28,41 \\
\hline 4 & Alam & 103 & 120 & 17 & 16,50 \\
\hline
\end{tabular}

Source: RTMC Ditlantas East Java Regional Police

Based on the explanation above, we can see that the factors that cause traffic accidents are Human Error Factors; Driver Factor; Road Factor; Vehicle Factors; and natural factors.

First, the Human Error Factor

Namely in this case the causal factor of a traffic accident can be caused by a traffic violation factor. The improvement study that must be done is by giving counseling or socialization to the whole community so that they always obey the traffic rules. With the socialization, it is expected that the community will be more obedient and can minimize accidents that occur due to human error factors. Based on data obtained from the RTMC Ditlantas Polda East Java traffic violations that occurred from January / May 2017 and 
Page 838-849.. ISBN: 978-602-6 988-75-1

Web Jurnal Online: jurnal.unmuhjember.ac.id

By: Ismail, Haryono, Permana Tedjo

Model Of Prevention Of Traffic Accidents

January / May 2018 are as the following table:

\begin{tabular}{|r|l|r|c|r|r|}
\hline \multirow{2}{*}{ No } & \multirow{2}{*}{ Uraian } & \multicolumn{4}{|c|}{ Januari - Mei } \\
\cline { 3 - 6 } & & $\mathbf{2 0 1 7}$ & $\mathbf{2 0 1 8}$ & \multicolumn{1}{c|}{ Angka } & \multicolumn{1}{c|}{$\%$} \\
\hline 1 & Jumlah Dak Gar Lnts & 683.093 & 865.547 & 182.454 & 26,71 \\
\hline 2 & DakGar Tilang & 446.161 & 478.374 & 32.213 & 7,22 \\
\hline 3 & DakGar Non Tilang & 236.936 & 387.177 & 150.241 & 63,41 \\
\hline
\end{tabular}

Source: RTMC Ditlantas East Java Regional Police

Based on the table, it is known that the number of traffic violations from January to May 2017 - January to May 2018. The number of traffic violations in January / May 2017 is 683,093 violations with 446,161 ticket violations, and the number of non-ticket violations 236,932 violations. While the number of traffic violations in January / May 2018 was 865,547 violations, up $26.71 \%$ from the previous year with the number of traffic violations 478,374 violations down $7.22 \%$ from the previous year, and the number of non-ticketing violations 387,177 violations rose $63.41 \%$ from the year previous. Data from the RTMC Ditlantas East Java Regional Police of the types of traffic violations that occurred from January to May 2017 and January to May 2018 are as follows:

Table 3 Types of Violations Occurred in Jan / May 2017 and Jan / May 2018

\begin{tabular}{|r|l|r|r|r|}
\hline \multirow{2}{*}{ No } & \multirow{2}{*}{ Jenis Pelanggaran } & \multicolumn{3}{|c|}{ Januari - Mei } \\
\cline { 3 - 5 } & & \multicolumn{1}{|c|}{$\mathbf{2 0 1 7}$} & $\mathbf{2 0 1 8}$ & \multicolumn{1}{c|}{ Trend } \\
\hline 1 & Batas Muatan & 14.042 & 14.156 & 0,82 \\
\hline 2 & Batas Kecepatan & 2.839 & 8.472 & 198,40 \\
\hline 3 & Marka Jalan/Rambu-2 & 110.338 & 162.175 & 46,98 \\
\hline 4 & Surat Surat & 196.527 & 176.894 & $-9,99$ \\
\hline 5 & Perlengkapan & 36.680 & 32.777 & $-10,64$ \\
\hline 6 & Tdk Pakai Helm & 50.439 & 50.424 & $-0,03$ \\
\hline 7 & Tdk Pakai Sabuk & 7.888 & 7.011 & $-11,12$ \\
\hline 8 & Lain-lain & 27.408 & 26.465 & $-3,44$ \\
\hline
\end{tabular}

Source: RTMC Ditlantas East Java Regional Police

Based on the table above, it can be seen the comparison of traffic violations in terms of the types of traffic violations from January to May 2017 with January to May 2018. The number of types of traffic violations in January to May 2017 is 487,311 violations with the types of violations the load limit in January to May 2017 is 14,042 violations, the type of violation of the speed limit in January to May 2017 is 2,839 violations, the type of violations of road markings / signs in January to May 2017 is 110,338 violations, types of letter violations -the letters in January to May 2017 were 196,527 violations, the type of violation of equipment requirements in January to May 2017 was 36,580 violations, the types of violations not wearing helmets from January to May 2017 were 50,437 violations, the types of violations were not wearing belts 7,888 violations, the types of other violations from January to May 2017 are 27,408 violations.

While the number of types of traffic violations in January to May 2018 was $.478,374$ violations, up $7.22 \%$ from the previous year with the type of load limit violations in 
Proceeding ICOGISS 2019

Page 838-849.. ISBN: 978-602-6 988-75-1

Web Jurnal Online: jurnal.unmuhjember.ac.id

By: Ismail, Haryono, Permana Tedjo

Model Of Prevention Of Traffic Accidents

January to May 2018 was 14,156 violations, down $0.82 \%$ from the previous year, the type of speed limit violation in January to May 2018 was 8,472 violations, up 198.40\% from the previous year, the type of violations of road markings or signs in January to May 2018 was 162,175 violations, up $46.98 \%$ from the previous year, the type of violation of the documents in January to May 2017 was 176,894 violations, down 9.99\% from the previous year, the type of violation of equipment requirements in January to May 2018 was 33,777 violations, down $10.64 \%$ from the year previously, the types of violations not wearing helmets from January to May 2018 were 50,424 violations, down $0.03 \%$ from the previous year, the types of violations not wearing belts in January to May 2018 were 7,011 violations, up $11.12 \%$ from the year se Previously, the types of other violations in January to May 2018 were 26,465 violations, down 3.44\% from the previous year.

RMTC Ditlantas Polda East Java also collects data on the types of vehicles that commit traffic violations that occurred from January / May 2017 and January / May 2018 are as the following table:

Table 4 Anev Data from the Vehicle Type (January to May 2017 and Jan to May 2018)

\begin{tabular}{|r|l|r|r|r|}
\hline \multirow{2}{*}{ No } & Pelanggaran & \multicolumn{3}{|c|}{ Januari - Mei } \\
\cline { 3 - 5 } & Kendaraan & \multicolumn{1}{|c|}{$\mathbf{2 0 1 7}$} & \multicolumn{1}{c|}{$\mathbf{2 0 1 8}$} & \multicolumn{1}{c|}{ Trend } \\
\hline 1 & Roda 2 & 366.293 & 376.769 & 2,86 \\
\hline 2 & Pribadi & 29.423 & 36.311 & 23,41 \\
\hline 3 & Pick Up & 15.278 & 16.381 & 7,22 \\
\hline 4 & Truck & 28.615 & 40.748 & 42,40 \\
\hline 5 & Angkot & 3.314 & 3.884 & 17,21 \\
\hline 6 & Taxi & 421 & 403 & $-4,33$ \\
\hline 7 & Bus & 2.817 & 3.878 & 37,66 \\
\hline
\end{tabular}

Source: RTMC Ditlantas East Java Regional Police

Based on the table above, it can be seen that the number of traffic violations in terms of types of vehicles in January to May 2017 with January to May 2018. The number of traffic violations in terms of types of vehicles in January to May 2017 is 478,374 violations with the type of bus vehicle is 2,817 violations, the type of truck vehicle is 28,615 violations, the type of angkot vehicle is 3,341 violations, the type of private vehicle is 29,423 violations, the type of taxi vehicle is 421 violations, the type of vehicle 2 wheels is 366,293 violations, the type of pickup vehicle is 15,278 violations. While the number of traffic violations in terms of types of vehicles in January to May 2018 was 478,374 violations, down $7.22 \%$ from the previous year with 3 types of Bus vehicles were 2,878 violations, up $37.66 \%$ from the previous year, types of Truck vehicles were 40,748 violations, up $42.40 \%$ from the previous year, the type of vehicle Angkot 3,884 violations, up $17.21 \%$ from the previous year, the type of Private vehicle was 36,311 violations, up $23.41 \%$ from the previous year, the type of Taxi vehicle was 403 violations, down $4.33 \%$ from last year, the type of 2 -wheeled vehicle was 376,769 
violations, up $2.86 \%$ from 2017, the type of Pick Up vehicle was 16,381 violations, up $23.41 \%$ from the previous year.

Based on the results of an analysis conducted at the RTMC Ditlantas East Java Regional Police which are included in the traffic violation factor as a factor causing traffic accidents are violations committed by drivers that have an impact on laka and then usually violate traffic signs or road markings, exceeding the load limit ignoring safety standards.

Second, the Traffic Signs Factor

The presence of traffic signs is also very influential in the occurrence of accidents. On urban roads or dense residential areas, industrial areas, markets, schools and residential areas are factors in the presence of traffic signs can cause high accidents. For example, on a densely populated road as mentioned most often used as a shoulder of the road as a stop or a rise and fall of passengers. This of course narrows the space for other vehicles and raises the potential for traffic accidents.

In the article Azzam SyahidAnnasai (Kompasiana.com, 2018), about Without Signs Then Intas, Safe ?, mentioned the results of the analysis of the factors causing traffic accidents there are 3 factors: Human Factors, Vehicle Factors, and Environmental Factors. Of the three factors, interrelated to cause accidents, therefore the necessary implementation of traffic signs users and their types correctly, the implementation of traffic signs can be done by means of interaction between traffic sign officers with drivers / pedestrians. If the traffic signs have been installed correctly by the traffic sign officer, this is where there will be interaction with the driver / pedestrian to be able to see the sign and understand the provisions on the highway in order to minimize the occurrence of traffic accidents Third, the Road Factor

Road factors referred to include speed of the road plan, road geometric, safety fence in mountainous areas, whether there is a road median, visibility, and road surface conditions. Damaged or potholes can cause accidents and can endanger road users, especially for road users.

As a basis for moving a vehicle, the road needs to be planned or designed carefully and thoroughly with reference to the description of the development of vehicle volume in the future. Road design must be in accordance with standard specifications and be done in the right way and obtain adequate maintenance, aiming to provide safety for the wearer. On the other hand the properties of the road also affect and can be a cause of traffic accidents.

There are several things from parts of the road that can cause accidents, are: a. Damage to the road surface (for example, there are large holes that are difficult for drivers to avoid); b. Damaged / imperfect road construction (for example the location of the road shoulder is too low when compared to the surface of the road, the width of the pavement and the shoulder of the road are too narrow); c. Imperfect road geometries (for example, superelevation on bends too steep or too gentle, bend radii too small, driver free vision is 
Proceeding ICOGISS 2019

Page 838-849.. ISBN: 978-602-6 988-75-1

Web Jurnal Online: jurnal.unmuhjember.ac.id

By: Ismail, Haryono, Permana Tedjo

Model Of Prevention Of Traffic Accidents

too narrow, combination of vertical and horizontal alignments is less appropriate, descent and increment of roads are too steep, etc.).

Based on the results of the analysis, which was carried out at RTMC Ditlantas Polda East Java which included in the road factor as a cause of traffic accidents is the environment and road conditions that are damaged, perforated, geographically sloped, curved, incline or dangerous road derivatives and street lighting. With this analysis, in order to minimize traffic accidents, the government in this case must pay more attention to road improvements so as not to endanger the road users. Fourth, Vehicle Factors

The most common vehicle factors are broken tires, brakes not functioning as they should, metal fatigue resulting in broken vehicle parts, worn equipment that has not been replaced, and various other causes. The overall factor of the vehicle is very much related to the technology used, the care it takes on the vehicle. To reduce the factor of vehicle maintenance and vehicle repair needed, besides that there is an obligation to conduct regular motor vehicle testing. Feasibility of motorized roads, condition of motor vehicles, transmission of motor vehicles, tires of motorized vehicles and other safety standards.

Vehicles can be a factor in traffic accidents if they are not driven properly, as a result of technical conditions that are not roadworthy or the use of vehicles that are not in accordance with the rules. As for the causes of traffic accidents caused by vehicle factors are as follows: First, Vehicle Equipment: Brake tools do not work well, for example brake failure; Steering gear does not work well; Poor condition tires or wheels or broken tires; Broken front or rear axles. Second, Vehicle Lighting: Does not meet the lighting regulations; Use lights that dazzle other vehicle drivers. Third, the use of vehicles that are not in accordance with the provisions, for example vehicles that are overloaded or overloaded.

As for those included in the vehicle factor as a cause of traffic accidents based on the results of the analysis conducted at the RTMC Ditlantas East Java Regional Police are: the feasibility of the motorized road; condition of motorized vehicles; motorized vehicle transmission; tires from motor vehicles and other safety standards. From the results of the analysis there must be control from the relevant authorities in the vehicle feasibility test in order to minimize the number of accidents.

Fifth, Natural Factors

In addition to the four other factors above, there are also other factors that contribute to traffic accidents. As with natural factors, for example weather that can also contribute to accidents, the intended weather factor that causes traffic accidents is the rainy weather factor that can affect the driver's visibility and vehicle performance. Smoke and fog can interfere with visibility, especially in mountainous areas.

Based on the results of an analysis conducted at RTMC Ditlantas Polda East Java which included in the road factor as a factor causing traffic accidents are natural conditions such as natural disasters (floods, earthquakes, landslides, tsunamis, typhoons, etc.), bad weather and thick fog. Natural factors are factors that we cannot control as a whole. However, we can also minimize so that there are not many accident victims that occur 
due to natural factors, for example in the event of floods, landslides, hurricanes, etc. so that vehicle drivers must be vigilant in dealing with accidents due to natural factors.

Prevention Model for Minimizing Traffic Accidents

To reduce the number of traffic accidents, the East Java Regional Police Directorate of Traffic held an operation with the code of Simpati Semeru 2019. The operation was held for 14 (fourteen) days. This operation prioritizes guiding vehicle users. Based on the results of an analysis conducted at the East Java Regional Police East Java Traffic Directorate, several methods or efforts to prevent or reduce the causes of traffic accidents are mentioned, namely two methods namely pre-emptive and preventive methods. Preemptive methods include, for example, the implementation of Binluh, installing banners, leaflets and brochures in strategic places on the lane-prone area and then with the theme of traffic safety or driving, and also the active implementation of patrol in prone areas for traffic jams and laka. Whereas preventive measures include, for example, assisting road users, directing pedestrians to cross places that have been determined, and also increasing active enforcement in the form of stationary and mobile raids with potential targets for violations that could lead to traffic accidents through traffic and warning.

Based on the opinion of respondents as many as 30 students of the Social Sciences University of Bhayangkara Surabaya, there are 8 solutions that can be done in order to prevent traffic accidents so that victims of accidents decrease, here are 8 strategic steps that can be taken to reduce traffic accidents or traffic accident prevention models 


\section{Conclusion}

The results of the analysis of the study of the factors that cause traffic accidents in an effort to improve the prevention of traffic accidents are as follows: That there are 5 Factors that cause traffic accidents, namely: First, the Human Error Factor caused by traffic violations. Second, the Traffic Signs Factor, there is interaction with the driver / pedestrian to be able to see these signs and understand the provisions on the highway. Third, Road Factors, namely the environment and condition of damaged roads, holes, geographical slopes, bends, climbs and dangerous road derivatives and street lighting. Fourth, Motorized Vehicle Factors as factors that cause traffic accidents include: motor vehicle roadworthiness, motor vehicle condition, motor vehicle transmission, tires from motorized vehicles and other safety standards. Fifth, the Natural Factor, is a factor which we cannot control as a whole. But it can still minimize so that not many accident victims that occur due to natural factors. Efforts to prevent traffic accidents can be done with education through videotrons, pocket books and online media for traffic drivers and related parties about driving safety behavior and traffic ethics, the existence of unique accessories and trendy t-shirts with reflector technology for traffic safety, preparation of a location database Prone to traffic accidents, Making eco smart trafficlight as a detection of traffic light violations, Creating an Android-based traffic sign notification system in every motorized vehicle to reduce traffic violations, Making sleepiness shock detection technology on motorists with computer vision systems as a step to minimize accidents traffic, Creating an intelligent transportation system for traffic, Empowering the bikers 
Proceeding ICOGISS 2019

Page 838-849.. ISBN: 978-602-6 988-75-1

Web Jurnal Online: jurnal.unmuhjember.ac.id

By: Ismail, Haryono, Permana Tedjo

Model Of Prevention Of Traffic Accidents

\section{REFERENCE}

Basumerda, C., 2014, Pengaruh Jenis Edukasi Keselamatan Berkendara Terhadap Pemahaman Calon Pengendara Mobil Dalam Menghadapi Konflik Lalu Lintas, Tesis Program Studi Pascasarjana Teknik Industri Universitas Gadjah Mada, Yogyakarta.

Chen, C.F., 2009, Personality, Safety Attitudes And Risky Driving Behaviors-Evidence From Young Taiwanese Motorcyclists, Accident Analysis and Prevention, 41, 963968.

Crundall, D., Andrews B., Loon E., Chapman P., 2010, Commentary Training Improves Responsiveness to Hazards in a Driving Simulator, Accident Analysis and Prevention 42, 2117-2124.

Dephub, 2009.UU No. 22 tahun 2009 tentang Lalu Lintas dan Angkutan Jalan.<http:// hubdat.dephub.go.id/uu/288-uu-nomor- 22-tahun-2009-tentang-lalu-lintasdanangkutan- jalan> [Sitasi 10 Oktober 2017].

Dian Tiara (2017) Pengaruh Jenis Edukasi Terhadap Performansi Pengemudi dengan Karakter Risk Taker. Forum Teknik Vol. 37, No. 1, Januari 2017. Pascasarjana Teknik Industri, Fakultas Teknik, Universitas Gadjah Mada

Gregersen, N.P., Engstrom, I., Hernetkoski,K., dan Nyberg, A., 2003, Young Novice

Drivers, Driver Education And Training Literature Review, VTI rapport 491A, Swedish National Road and Transport Research Institute, Linkoping.

Haryoko, S., 2009, Efektivitas Pemanfaatan Media Audio Visual Sebagai Alternatif Optimalisasi Model Pembelajaran, Jurnal Edukasi, vol 5 no 1.

JawaPos.com, 2018. 2018, Pelanggar Lalu Lintas di Surabaya Naik 9 Persen. 31 Desember 2018.

Kompasiana.com, 2019. Tanpa Rambu Lalu Lintas, Amankah? 5 Desember 2018

Kusumadewi, S., Hardjajani, T., \& Priyatama, A.N. (2012).The correlation between The Social Support of Peer Group and Self-control Towards The Obedience of The Rule in The Teenage Girls of The Assalam Modern Islamic Boarding School Sukoharjo. Surakarta: Program Studi Psikologi Fakultas Kedokteran Universitas Sebelas Maret. <http://candrajiwa.psikologi.fk.uns.ac.id/index.php/candrajiwa/article/viewFile/25/ 15> [Sitasi 24 Juli 2018].

Maya, Simamora, A,(2011),Analisa Kecelakaan Lalu Linta Di Jalan Tol Belmera,Tugas Akhir, Jurusan Teknik Sipil, Universitas Sumatera Utara. MedanDefia Rosalina Anwar, 2018. Analisis Risiko Kecelakaan Lalu Lintas Berdasar Tipe Kepribadian Dan Pelanggaran Pada Pengendara Sepeda Motor. The Indonesian Journal of Public Health, Vol. 12 No. 2, Desember 2018: 179-189

Miles, Matthew B., dan Huberman, A.Michael. 1992. Analisis data kualitatif Terj. Tjejep. Rohidi. Jakarta : UI Press,

Nabi, Sila, Franchois, Chiron, Lafont \& Emanuel. 2005. Type A Behavior Pattern, Risky Driving Behavior and Serious Road Traffi c Accident: A Prospective Study of the Gazel Cohort.American Journal of 
Page 838-849.. ISBN: 978-602-6 988-75-1

Web Jurnal Online: jurnal.unmuhjember.ac.id

By: Ismail, Haryono, Permana Tedjo

Model Of Prevention Of Traffic Accidents

Epidemiology.<https://oup.silverchaircdn.com/oup/backfile/Content_public/Journa 1/aje/170/4/10.1093/aje/kwp161/2/kwp161.pdf >[Sitasi 28 Juli 2018].

National Highway Traffic Safety Administration, 2009, TRAFFIC SAFETY FACTS 2009:

A Compilation of Motor Vehicle Crash Data from the Fatality Analysis Reporting

System and the General Estimates System, U.S. Department of Transportation, Washington, DC 20590.

Reason, J., Manstead, A., Stradling, S.,Baxter, J., dan Campbell, K., 1990, Errors And Violations On The Roads: A Real Distinction? Ergonomics, 3 .1315-1332.

RTMC DITLANTAS POLDA JATIM.

TribunJatim.com, 2019. 45 Persen Kecelakaan Lalu Lintas Di Surabaya Libatan Anak Milenial, Karena Terburu-Buru \& Alkohol

Utari, Gineung Cynthia. 2010, Hubungan Pengetahuan, Sikap, Persepsi Dan Keterampilan Mengendara Mahasiswa Terhadap Perilaku Keselamatan Berkendara (Safety Riding) Di Universitas Gunadarma Bekasi. Skripsi. UIN Syarif Hidayatullah Jakarta.

WHO. 2015. Global Status Report on Road Safety 2015. Geneva: Management of Noncommunicable Diseases, Disability, Violence, and Injury Prevention (NVI).

Tersedia di <http://www.who.int/violence_injury_prevention/road_safety_status/2015/GSRRS 2015_Summary_EN_final2.pdf?ua=1 $>$ [Sitasi 27 Juli 2018].

Wright, T.P., 1936, Factors Affecting the Cost of Airplanes, Journal of the Aeronautical Sciences, 3(4), 122-128. 